\title{
EVOLUTION OF HEALTH CARE IN INDONESIA
}

\author{
Junardi Harahap \\ Department of Anthropology \\ Faculty of Social Science and Political Science \\ Universitas Padjadjaran, Bandung, Indonesia \\ junardiharahap@gmail.com
}

\begin{abstract}
The evolution in the field of health care has been going on for quite a long time in the Indonesian society. The development of the evolution of health care in the city of Bandung, Indonesia, has developed in line with the development of the city itself. Research question in this study focuses on the evolution of health care in the city of Bandung, Indonesia. This study used a qualitative approach using the methods of observation and interview. The findings of this study showed that the health service in the city of Bandung, Indonesia, starting with the traditional treatment methods in traditional medicine, are held by dukun in general and women's health services are performed by paraji which is to place health services conducted in the homes of the population. However, the development of the service is starting to disappear because of modernization, replaced with health services performed by physicians and other health paramedics. Ffurthermore, a growing ministry is also carried out at Posyandu, Puskesmas, and hospitals. Nevertheless, health services performed by dukun and paraji remain there even though in only a small scale and done in secret.
\end{abstract}

Keywords: Anthropology, Evolution, health, dukun and paraji

\section{INTRODUCTION}

The evaluation of health development in Bandung is a long journey which is very complex and goes into lengthy changes. It started from a long journey departing from the long traditional era coming from the long kingdom era in keeping the wisdom of the nation. Nations that come from the long traditional era are also from the nations with a long traditional era. The management of the nation took a long time and filled with various experiences. The era of the society that always leads to long problems. Indonesian society is a society that has long and strong cultural roots that will strengthen the great nation.

Tradition-based society has a lot of local wisdoms related to a lot of things based on the evolution of existing health in the community. The course of history has brought a lot of changes in society. Communities that led to the changes in historyhas led to a lot of things that bring the history of society that leads to a lot of things that bring people to the health. The health has brought changes to the health in the city. People who support the historical dimension of health leads to the things that bring the community to move in historical terms. The research itself was conducted using qualitative approach taken by observation and interview.

\section{RESEARCH METHODOLOGY}

This study used a qualitative approach using the methods of observation and interview InThe evaluation of health development in Bandung.

\section{LITERATURE REVIEW}

Levin \& Browner (2005: 746) argues that the conception of the anthropological concept of health is a cross-cultural variation in the moral behavior of the perpetrators. Baer (1997: 1565) states that the community is an important part of the strategy and the construction of culture in health which has led to a variety of perspectives in health. Barrett (1997: 585) mentions that medical anthropology actsas the medical culture as well as the mediumof the health problems that exist in the society. Anglin (1997: 1368) illustrates the direction on the health care created by the community with a variety of methods performed in all treatments. Khan (2006: 2786) provides the guidance that actually there are a lot of treatment pluralism existing in our health system.A variety of previouslyconducted studies related to health problems are, among others, Harahap (2008); Harahap (2014); Harahap (2015); and Harahap ( 2015).

\section{RESULTS AND DISCUSSION}

Communities that lead to a lot of things that bring the community to the life and society. Community and health are the lives in life and community life that leads to good things. Community is an important part of society and the culture in the community is a number of things that lead to other things. Communities are a few things that are related to health and leadto many things in health. 
Evolution of health is an important thing to understand as part of a culture that must be maintained and must be preserved properly. It is because for the community, health is a thing that must be understood properly in their culture. Culture is a significant part in a society that must be maintained and preserved. A society will remain a major part in the community and should remain a part of the existingculture and must be maintained and preserved well.

This means that a culture as an important part of the long journey of a great nation and state does not only stand from one entity alone but as a part of the health. Society is a necessity that does not only make mistakes made by the public health. The society in the health-based area is something that must be performed well.

Society is for those who have a lot of things that make a lot of things easy to understand by the local community. Apart from the results obtained with health needs. Society is a healthy process of movement that brings health. Society is how health is done within the framework of society. Society is an unforgettable part because it comes from the culture that has taken deep roots. Society is a very important part done based on health and others. Society must be done to obtain a part of good health and the simulation of the overall health. Health is an important part in Bandung community who is very concerned about health as a part of life and part of a long tradition.

The long part of the national culture is an important part of society that has been developed over time. Community is an important part that must still be done properly as part of the important things that bring people important things for our society that should always be done properly that it becomes an important process for our society.

West Java community is a community that brings a lot of fundamental changes in society that bring a lot of changes as well as interesting and traditionalthings that brings many benefits and affect many things in life that are done well. Traditional is a concept declaring thatevery life departs from the holistic. Community is an important part in achieving the health objectives that need to be fully understood by considering the local knowledge in the best possible way.

What is done is actually a process that is ongoing and continues well and executed properly. It is important to understand the ever-changing society based on the traditional point of view which is very important in understanding a culture that has developed well and is also going well and it is also true and good in accordance with the traditions.

Besides interesting, doing manybecomes an important part in a society performs a variety of important and traditional policies. Health is a habit that begins with a variety of matters relating to the health. A variety of health conditions has brought many things to the society. Society is the thing that brings a balance to the health. Health should be done in the community that brings many things to the society. Health is an important part that must beperformed using the cultural approach applied by the people. People who bring a lot of changes will make a better life. Health is an important part for people who do a lot of things in our society.

The society that is under the wave of health becomes an integral and major part of the health system in our society. The society who is an important part in the community will push a lot of things to move in the society which we understand as an important issue in our lives.

\section{CONCLUSION}

The evolution of the health system in Bandung actually started from the activities that have been going well in the area of Bandung which conduct traditional treatments. The treatments obviously relates to the traditional issues, such as taking herbal medicines and having traditional treatments. The treatmentsthat are the foundation of the society still implement social aspects in life that relates to those associated with traditional treatments. The conclusion that can be submitted here is that the development and history of the health evolution in Bandung is a totally long process to live in the health life experienced by the society.

\section{REFERENCES}

[1] Anglin, M.K.(1997). Policy, praxis, and medical anthropology: Introduction: Health policy and health praxis in the United States-A symposium. Social Science \& Medicine, 44, (9): 1367-1369.

[2] Baer, H.A. (1997).The misconstruction of critical medical anthropology: A response to a cultural constructivist critique. Social Science \& Medicine, 44, (10):1565-1573.

[3] Barrett, B.(1997). Identity, ideology and inequality: Methodologies in medical anthropology, Guatemala 1950-1995. Social Science \& Medicine, 44(5):579-587.

[4] Harahap, J. 2008. Fadhillah Tumbuhan Herbal dan Perubatan Islam.(Plant Advantage Herbal and Islamic Medical). Selangor Malaysia: Prosedings Scientific Conference III Persatuan Pelajar Indonesia UKM, Building Scientific Culture, Creating Expertise, Establis hing Network.

[5] Harahap, Junardi. 2015. Kemuning: An Analysis Of Anthropology Of Health. Procedings 2nd International Conference on Global Trends in Academic Research.Full Paper Proceeding GTAR-2015, Vol. 2, 247-252.

[6] Harahap, Junardi. 2015. Bekam Treatment: Cheap, Holistic And Changes Paradigm.Procedings 2nd International Conference on Global Trends in Academic 
Research. Full Paper Proceeding GTAR-2015, Vol. 2, 253-257.

[7] Harahap, J. (2014). Respons Masyarakat Terhadap Pembangunan Sektor Kesihatan di Desa Ciburial Indonesia (Community Response to Development of Health Sector in the Village Ciburial Indonesia). Selangor: Tesis Ph.D National University of Malaysia.

[8] Levin, B.W. \& Browner, C.H. (2005). The social production of health: Critical contributions from evolutionary, biological, and cultural anthropology. Social Science \& Medicine, 61, (4):745-750.

[9] Khan, S.(2006). Systems of medicine and nationalist discourse in India: Towards "new horizons" in medical anthropology and history. Social Science \& Medicine, 62, (11),:2786-2797. 